\title{
Development Process of Banking Regulations in Turkish Legal System
}

\author{
Yasam Demir, (PhD) \\ Sebnem Yalcin, (PhD) \\ Pamukkale University,Turkey
}

doi: 10.19044/esj.2017.v13n4p1 URL:http://dx.doi.org/10.19044/esj.2017.v13n4p1

\begin{abstract}
The regulation of banking sector recently has become one of the discussed issues after the crisis experienced in developed and developing countries. The opinion that the international regulations and standards are not enough for the surveillance and audit of the banks, has began to prevail. In this aspect, the regulations, which every country has done in the scope of internal dynamics, took attention. In this study legal regulations that Turkey, where the negative effects of 2008 crisis are seen relatively less than European countries, has besides having international banking standards are analyzed. The development process of Banking Law is examined in respect to the historical process.
\end{abstract}

Keywords: Turkish Banking Laws, legislation, regulation

\section{Introduction}

Banking activities affect the money market, the capital market and the credit markets. The negativities that may arise in these markets lead to dimensions that could harm the welfare of the society and the public interest by creating dispersion and externalities. In fact, when the costs of the 1994, 1998, 2000 and February 2001 in Turkey were taken into account, it became a priority to prevent the possible negative developments that could happen in the banking sector and the regulations in this field, was emphasized ${ }^{1}$.

Regulations related to banking legislation consist of the Banking Law No. 5411 dated 19/10/2005 and the guidelines and notifications based on this law. Within the scope of the related law, the BRSA (Banking Regulation and Supervision Agency) was created on the basis that the regulation processes took a long time in the rapidly changing financial market conditions. The BRSA has been authorized to accelerate, regulate, supervise and take

${ }^{1}$ 2000-2001 The February crisis counts a cost of US \$ 53.6 billion for the country economics as nearly a third of the national income (BRSA, 2010). 
precautions for legal bureaucracy. The independent body authorized to make sub-regulations related to the Law is the BRSA.

During the time that these regulations were in force, international organizations also influenced. Thus, in the letter of intent of January 2002 issued to the IMF in 2002, the section under the heading of Banking Reform gave information about legal arrangements such as capital adequacy of BRSA, credit provisions, processes related to problematic banks, transition to accounting system in compliance with International Accounting Standards ${ }^{2}$.

It is of capital importance that regulatory and local legislation are in compliance with international standards, an auditable and observable banking system is established and transparency is ensured in order to maintain the stability of the system. In this way, it was desired to provide a reliable investment area. In this context, it may be said that the legal regulations in the economic area are influenced by the growth policies of the countries and the macro indicators targets.

\section{Banking Law}

Banking law constitutes the main source of banking law. The first law in this field was the Deposit Protection Law No. 2243, which was adopted in 1933. This law was later followed by the Banking Law No. 2999, which entered into force in 1936 and the Banking Law No. 7129 which entered into force in 1958. In 1985, the Banking Law No. 3182 entered into force (TBB, 1998).

In these laws, as clearly stated in the preamble of the Law No. 7129, the good management of the banks is necessary for the protection of the interests of both the shareholders and the depositors as well as for the protection of the interests of national economics.

With the same preamble, it was emphasized that banks using public savings should be under the inspection of the public authority more strictly and constantly, except the inspection and supervision applied to the companies according to the laws due to the activities that benefit the country's economy, similar to public institutions (Kuntalp, 2004: 68). Taking these reasons into consideration, the importance given to the regulation of the banking sector is clearly stated.

\footnotetext{
${ }^{2}$ See.http://www.tcmb.gov.tr/wps/wcm/connect/TCMB+TR/TCMB+TR/Main+Menu/Yayinl ar/Temel+Politika+Metinleri/IMF+Niyet+Mektuplar (access date: 12.07.2015) In particular, the letter emphasizes the positive impact of foreign capital on investments in macroeconomic targets.
} 


\section{Banking Law No: 3182}

Banking Law No. 3182 entered into force by being published in the Official Gazette dated 02.05.1985 and numbered 18742; later it was amended by the laws numbered 3222, 3291, 3332 and 3494. There were amendments in banks, credits and other investments, and regulations about professional discipline and audit by the legislative decree prepared in $1994^{3}$.

Following the globalization movement that began in the 1980s, when this law entered into force, the structure of the financial markets began to change. Especially the increase of the number of companies and the concentration of the competition have caused the banks to undergo structural changes. Despite the increase in the variety of products and services, the banks still faced different risks due to the developing and changing market conditions, which led to the creation of financial crises.

With the liberalization of the economies, the exchange regime, free money circulation and the proliferation trade between countries have led to the spread of financial crises in countries. As a matter of fact, Mexican and Asian crises had a negative impact on the world economy with a contagious effect (BRSA, 2010).

In particular, political instability, the increase in the volume of problematic credits in banks and inadequate public finance policies have been shown as the reasons for these crises. In addition, structural weaknesses such as lack of corporate governance in the finance sector and insufficient monitoring of the quality of the receivables of the banks were also cited as reasons for the crisis. It was stated at report of Industry and Technical and Commercial Budget Commission Decree-Law.

\section{Banking Law No: 4839}

In parallel with these adverse developments in the financial markets in the world, regulations requiring more effective surveillance and audit were needed, and the Basel Standards were announced in 1997 for this purpose. It was manifested that the Banking Law No. 3182 functioning in force, were inadequate against these developments in terms of scope and functioning. The new Banking Law No. 4839 entered into force in 1999 in order to adapt to the changing international conditions and meet the needs ${ }^{4}$.

\footnotetext{
${ }^{3}$ See Industry and Technical and Commercial Budget Commission Decree-Law numbered B.02.0.KKG/101-1-321/03857 dated 22/06/1994

${ }^{4}$ See. Banking Law Draft and numbered B.02.0.KKG/101-1028/1481 dated 30/03/2005 and European Union Compliance and Plan and Budget Commissions Reports, p.5
} 
In this context, the Banking Law numbered 4839 dated 23.06.1999 entered into force and "Banking Regulation and Supervision Agency" (BRSA) was established with this law ${ }^{5}$.

The mentioned law was amended by the "Law on Amendments to the Banking Law" on 17.12.1999, shortly after its entry into force. With this amendment, the powers belonging to the Council of Ministers were transferred to the BRSA at all stages from the institutions related to banks to their liquidation.

The first reason for this amendment in the Banking Law No. 4389 is to ensure that the bank auditing and supervisory authority is transferred from the Council of Ministers which is the political authority, to the BRSA that is an independent administrative authority, in accordance with international standards.

The other reason for the amendment is that clear and comprehensive regulations should be done by adopting appropriate auditing principles in accordance with EU Directives.

The other amendment adopted in the Banking Law No. 4389 is related to the determination of the board members of the BRSA. Previously, the members of BRSA were elected by the Council of Ministers among the candidates nominated by the Under secretariat of Treasury, The Turkish Republic Central Bank, the Union of Banks of Turkey, State Planning Organization (SPO) and the Capital Market Board (CMB); after the amendment, the BRSA members are appointed by the Council of Ministers by majority of votes with the recommendation of the related Minister among the candidates in the banking sector ${ }^{6}$.

Subsequent amendments to banking law have been in restorative legal regulations aimed to harmonize with financial developments in the world and international regulations.

Among the international regulations based on the amendments in the banking law, the most important of them are directives issued by the European Council in line with the developments in the markets.

Directives on the principles, the operational fundamentals, supervision and auditing of credit institutions between 1973 and 1992 were published by the Council of Europe and consolidated in a single booklet in

\footnotetext{
${ }^{5}$ See. Banking Law Draft and numbered B.02.0.KKG/101-1028/1481 dated 30/03/2005 and European Union Compliance and Plan and Budget Commissions Reports, p.7

${ }^{6}$ With this amendment, there is a dissenting opinion that all members of the BRSA, who are authorized to make macro-level adjustments to the country's economy, should be from the banking sector. In the opinion of the opposition, it is stated that if there is a disagreement between the government and the Board, there should be a structure that would represent the national will, (Akcaer, 2000, p. 97-128).
} 
2000. In 2001, the liquidation and restructuring processes of credit institutions are attributed to certain standards with the directive numbered 2001/24/EC issued by the Council of the European Union. The directive numbered 2001/65/EC issued in the same year brought practices for the determination and accounting recognition of the asset values according to international standards.

In the formation of the directive on International Financial Reporting Standards numbered 2002/1606/EC, Enron Cases were triggering factor as well as the accounting tricks of the Italian Parmalat Food Group and balance sheets and statements misleading the people who works with stocks and other market transactions. In the banking sector, reaction regulations, in other words if an event happens, the regulations preventing the repetition of this event are prevalent.

The "Financial Services Action Plan Report" was prepared by the Council of the European Union in 20047. In this report, it was accepted that financial markets and financial institutions are needed to be audited by an independent authority in order for the supervision of cross-border activities of financial institutions and institutions formed in a competitive market, common audit, common solution platform. These principles were later ratified by OECD countries such as China, Japan and South Korea as well as by the European Union.

The adopted regulations and measures taken did not prevent the crisis in the banking sector in December 2000 and the banking sector closed the year with a total loss of $\$ 4.2$ billion due to the crisis. In the ongoing February of 2001, the banking sector faced a second crisis. The duty losses of public banks, indirect loans of private banks to group companies, and the fact that the exchange rate was above what was expected, were the factors that increased the effects of the crisis. Within this scope, "Banking Sector Restructuring Program" was put into practice on May 15th, 2001.

The new risks that arose with globalization brought the need for amendments to Banking Law No. 4389 due to the changes in the market needs and in order to be able to pace with these changes. In these amendments, it was aimed to increase the legal power of the related law. In fact, as a reason for the adopted regulations, it was stated that the 3-year exemption granted to the public banks could cause unfair competition and amendment needed to be done in this respect. The fact that private financial institutions need to be subject to the Banking Law, was based on the reason

\footnotetext{
${ }^{7}$ See. Banking Law Draft and numbered B.02.0.KKG/101-1028/1481 dated 30/03/2005 and
} European Union Compliance and Plan and Budget Commissions Reports, p.3-5 
that the financial system would provide the stability and the competition as a whole.

In the period of being in force, the Banking Law No. 4389 was amended by Law No. 4491, 4672, 4684, 4743, 4842, 4969, 5020 and 5021 respectively and lastly amended by the Law No: 5354 that entered into force on 25th of May 2005. The related law, having been amended nine times during 5 years of time, made a new law necessary.

\section{Banking Law No: 5411}

The result of failure of the Banking Law No. 4389 to meet the requirements in the period of being in force, the banking law No. 5411 entered into force.

Making regulations to acquire timely information in a transparent and comprehensive level ensuring enlightenment of the public, providing the savings be directed to the credits in the areas that they could be efficient, securing the deposits of the depositors in a way that market discipline was not disrupted are among the aims of the law.

In the first article of the Banking Law No. 5411, the purpose of the law is stated as "to regulate the principles and procedures regarding the establishment of trust and stability in the financial markets, the effective functioning of the credit system and the protection of the rights and benefits of the account owners" 8 .

In the preamble of the first article of the law, it is stated that "confidence in the financial markets is provided by establishing clear and comprehensive market standards, reducing financial crime, establishing markets with sufficient depth and liquidity, ensuring trustworthy systems for the investors compliance with national and international amendments".

It has also been emphasized that the regulation of the behavior of the actors of the financial market and the functioning of the activities should be subject to be monitored.

Banking Law No. 5411 consists of 15 parts; general provisions, transactions subject to permission, corporate management, protective provisions, provisions related to collecting deposits and shares, auditing and measures to be taken, legal obligations, development and investment banks, and financial holding company, unions of institutions, provisions on BRSA, the provisions relating to the banks whose operational permission was taken

\footnotetext{
${ }^{8}$ This was also stated in the preambles of the Banking Law No. 5411, which entered into force on October 19, 2015 (İsiktac, 2010).
} 
and were transferred, provisions related to Saving Deposit Insurance Fund (SDIF), other provisions, the provisions on sanctions - investigation and prosecution and omitted and amended provisions. Law items; consist of general provisions, quality order rules and auxiliary rules for order rules (Tekinalp, 2009).

\section{General Provisions}

In the "General Provisions" section of the Banking Law, the purpose, scope, definitions and legal regulations explaining the activities are included in the law.

Ultimately, the aim of the Banking Law is to increase the effectiveness of the law in the banking sector and to determine the conditions under which the state fulfills its public duty with the responsibilities of the social state (Battal, 2004: 2).

The aim of the related law consists of four elements; to constitute a trust environment in the market, to provide stability, effective credit distribution and protection of rights. The first is to provide an environment of trust in financial markets. Banks should be trustworthy, prudent and honest in order to be trusted by the markets. The depths of the trustworthy markets are increasing, and they are becoming markets that quickly adapt to international standards having sufficient liquidity ${ }^{9}$. In order to maintain an environment of trust, it is necessary for the government to provide safeguards, to make regulations for the explanation for the public, to set the reports and standards for the market to be accurate, understandable and have access to sufficient information and to develop them. To meet these purposes, the Banking Law was prepared and the effectiveness of the related Law has been increased by detailing the sub regulations.

The concept of stability in financial markets is expressed as the continuation of the effectiveness of financial instruments and the continuity of the system in pricing, resource transfer and crisis periods. In order to ensure stability, it is necessary to make regulations and have effective monitoring of market operations taking into consideration possible risks related to the behaviors of actors in the market. Powers granted to the related institutions by the laws are included in the Banking Law. The BRSA was authorized by the relevant law to implement this purpose.

When we look at the order of the explanation of the purposes, when the first article of banking law is considered, it is primarily aimed to provide confidence and stability in financial markets. The next aim is expressed as

${ }^{9}$ See. Banking Law Draft and numbered B.02.0.KKG/101-1028/1481 dated 30/03/2005 and European Union Compliance and Plan and Budget Commissions Reports, p.17. 
"... the efficient functioning of the credit system..." (Banking Law, $3^{\text {rd }}$ article). The reason is that a reliable and stable market is firstly needed for effective credit system to be established. It is necessary for the credit system that the depositors and investors request to be included in a system based on trust. The credit system has an important effect on the development and growth of the country by providing savings into productive investments. Among the objectives of the related law in terms of effective operation of the credit system is the small difference between the deposit and the credit interest, the diversity of the service and the getting services at a fast and optimum cost.

The last statement of the first article of the Banking Law is "... to protect the rights and interests of the savings owners ...". Rights are the privileges that are favored for the person or institution recognized in the legal sense of the law (Yucel, 2010: 338). The rights and interests involved in this purpose are meant to be protected by the state so that the owners of the savings would feel safe. In this context, the application of deposit insurance for the protection of savings is a privilege reserved for the savings holders against other bank receivables, however keeping this guarantee at a certain limit is necessary to ensure market discipline. In fact, the guarantee of the majority of the deposits that could lead to missteps on trust has been one of the important factors affecting the banking sector in the past years. For this reason, while maintaining the rights of the savings owners, the aim of providing the market discipline should not be ignored. In this context, the legislative provisions on the capital and liquidity levels of banks in order to ensure market discipline are included in the Law.

Article 2 of the related law stipulates that "Deposit banks, participation banks, development and investment banks in Turkey, Turkish branches of such qualified institutions established abroad, financial holding companies, Turkish Banking Association, Turkey Participation Banks Association, Banking Regulation and Supervision Agency and Savings Deposit Insurance Fund and their activities". The banks established by special law were also included within the scope of the law and they were emphasized on the grounds that they were subject to their own laws as they were in the Law No. 4389 of the previous article and they were subject to the provisions of the Law No. 5411 at the same time. Although Turkish Republic Ziraat Bank and Halk Bank are state-owned public deposit banks established by special law, they left being a State Economic Enterprise, and became a joint-stock company. Having been registered in the Trade Register, with the main contracts by the government in accordance with the Decree Law No. 233, they were subjected to the fundamentals of joint stock 
Companies (Battal, 2010: 10). Vakiflar Bank Joint Stock Company founded in 1954 with the Law No. 6219 is still operating as a State Economic Enterprise. As the Central Bank was established as a joint stock company with the Special Law No. 1211, it is not subject to the provisions of the Banking Law although it is subject to the provisions of the Turkish Commercial Code.

\section{Rules Making Order}

It is possible to classify the rules for the provision of public benefit in the Banking Law as order rules. The purpose of these rules of order is to promote national savings through the banks in economic terms and to transfer them as real sector resources and to provide national development. In order for the legislator to achieve this purpose, it is necessary to establish the order, to ensure the continuity by supervising and observing the order. In this context, these rules regulate the principles of the bank's type, structure, fields of activity, organization and supervision. Powers such as restricting the activities of the banks when necessary, reducing their power and seizing their administration in the interest of protecting the public interest are also included in these regulations (Tekinalp, 2009: 4).

In order to achieve an order, common expressions should be used and non-interpretive limitations should be introduced. For this reason, these issues were clarified in Articles 1 to 5 of the Law and it has been governed by whom and which activities would be regulated under the relevant Law. Firstly, activities are defined in terms of the definition and scope of banks. In addition, these activities have been linked to the measures to be taken according to the result of the audit of the BRSA10. The power to interfere with bank operations was granted to BRSA in cases where it is necessary for public benefit as mentioned in Articles 70 and 88 of the related Law.

In our country which has a free market economy, the legislator controls the entry and exit to the market in the banking sector. The most important reason for this is to prevent the entry of people and institutions into the market that could lead to the disruption of the public order in the economic area. For this reason, supervision and control continue in the process from the first entry of the banks to the market till the exit from the market. For the institutions that want to enter in the market, the following issues are examined: partnership structure, sufficient financial power and required managerial experience, the functioning of the organization structure.

\footnotetext{
${ }^{10}$ See. Banking Law Draft and numbered B.02,0.KKG/101-1028/1481 dated 30.03.2005 and European Union Compliance and Plan and Budget Commissions Reports, p.17.
} 
Limitations and constraints imposed on these issues have been expressed between the article 6 and article 15 .

As the partnership structure of the banks is an important criteria in obtaining the establishment permission and activity permit; bank mergers, divisions, share exchange issues are also necessary to be regulated for the functioning of the sector. In these cases, since the partnership and capital structure or even the management structure will change, and this change will be subject to monitoring when the possible effect on the market structure and stability is taken into consideration. Another aspect of this is to prevent the formation of banks with enough market share to spoil the stability of the market in a possible negativity to a level that the market can be controlled. However, lawmakers have set an exceptional case for banks. In this context, in the merger, division and transfer transactions of the banks, it has been exempted from the provisions of Turkish Commercial Code (TCC).

Protection of Competition ${ }^{11}$. In addition, liquidation decisions of the banks, in other words decisions to exit the market, have also been subject to permission.

The order rules regarding the financial structures of the banks are stated in Articles 43-59 of the related law. These rules include the consolidation of the financial structure, the protection and sustainability of the financial structure, and the precautions to be taken when the structure is weakened. First of all, the financial adequacy must be measurable in order to determine the stability of the financial structure of the bank. In this context, the financial performance criteria adopted by international authorities are included in the Law. Lower limits for equity, capital adequacy and liquidity adequacy ratios have been defined as financial performance criteria. The aim of the lower and upper limit of the financial indicator measures is to ensure the public order by protecting the deposits of the depositors and preventing the acts which are distorting the competition. The necessary inspections and measures to prevent these rates from falling below the determined minimum ratio are taken under the authority of the BRSA.

The other issue, that was regulated, is loans (credits). The purpose of the arrangement of the loans is to regulate the banks' risk approach. Many of the activities for which the banks are risking are included in the definition of loans and a wide credit definition has been made in Article 48 of the Law. The main reason for broadening this scope is to prevent the lenders from

${ }^{11}$ Article 19 of the Banking Law stipulates that "... not exceeding twenty percent of the total assets of the banks being a subject to be transferred or merger ..." shall be excluded from the scope of the RCA. 
performing similar transactions indirectly and to ensure that their risks are at a manageable level. The statement "counts as credits" in the law is important for the following reason: if a transaction is considered a credit, it contains a risk element and it is necessary for the bank to take measures against this risk. The extent to which measures are taken is determined by the classified risk groups. It is aimed to ensure that the risks are traceable and controllable. In addition, limitations on the disbursement of loans are stated in Articles 54 and 55 of the Banking Act.

It is necessary to take preventive, corrective, remedial and restricting measures respectively in order to prevent the banks, which can not fulfill the regulations related to financial structure in order not to affect the system negatively. Audits and issues related to such measures are included in Articles 65 and 72 of the related Law.

Under the order rules; the regulations about the type of the establishment of the banks, areas of operation, procedures and forms of lending, balance sheet management and internal audit were also mentioned. Rules that increase the functionality of these rules can be categorized as auxiliary rules for order rules.

\section{Auxiliary Rules for Order Rules}

They are regarded as rules that do not constitute a single order which helps the order rules and these are necessary and guiding for the continuation of the ordering system. In the Banking Law, Corporate Management Principles and legal obligations can be evaluated within this scope (Tekinalp, 2009: 6).

Corporate Management Rules mentioned between the articles 22-42 of Banking Law, cover the management structure and processes necessary for the application of the rules of order in terms of banks. The relevant legislation was prepared taking into account the reports published by the OECD and the international standards adopted by the Basel Committee. In addition to these, the banks which are open to the public are also subject to the corporate management principles announced by the Capital Markets Board.

The Corporate Management Principles cover the principals that determine the management structure and determine the responsibility and authority areas for the managers. Within the framework of these principles, the board of directors is authorized to carry out supervision and surveillance activities. Within the scope of this authority, it is responsible for the detection of internal corruption and malicious intentions, prevention and 
improvement of these situations. As a requirement of this responsibility, it is necessary to establish a correct, transparent and reliable information system to inform the public. In this context, the following aspects are regulated; financial reporting in compliance with international standards, accounting standards, banks being subject to be monitored by independent audit firms and the principle of accountability. In addition, it is seen that the ownership structure related to the corporate management and the determination of the members of the board are effective in the behavior of the banks in the market. When the general manager is not a shareholder, in other words, not having capital ownership, it is perceived positively in terms of market value; whereas when they are a part of the board of directors, they prefer less risky investments (Tanrioven et al., 2006: 102). This result supports the necessity of corporate management principles.

Trust in the bank is the most essential element for the functioning of the financial system. The preservation of the reputation of the banks and the privacy of information about banks and customers are important for the continuity of this confidence and obligations related to these issues are stated in the Banking Law, Articles 73-76. These articles are; keeping the secrets; not carrying out behaviors that could damage the reputation of another bank, observing the ethical principles set by the Union of Turkish Banks, and observing the customers' right to obtain information. Other regulatory measures to increase the effectiveness of legislative regulations and to clarify the principles of implementation are referred to as secondary regulations.

\section{Conclusion:}

After the recent 10 years of financial crises, it was understood that the banking system mediated a widespread flow of money around the world, and this situation had an effect on the fragility of financial markets. In addition that there are the international regulations regarding the banking system to reduce the fragility of the financial markets, banking systems vary according to the structural characteristics of each country. It is possible to say that banking regulations applied in Turkey are in sufficient level to ensure stability in line with the purpose. Particularly in the 2008 crisis, the fact that the activities in the sector continued without failing can be regarded as an indicator. It is not enough to put the banks in an order only by legal regulations, structural measures and market inspections. In order to create a transparent market environment that will provide effective competition, it is necessary to increase the effectiveness of consumers and competitors. Given the application costs of regulations and the disruptive effects of state intervention on competition, the importance of raising awareness of other elements of the market is further increased. First of all, the power of the 
financial consumer is crucial for the people and institutions providing loans and deposits from banks. As the level of knowledge about the market of the financial consumer increases, the market dominance will also increase accordingly. For this, financial literacy should be widespread. It is necessary to increase the functioning of the action plans under the ,"Circular Letter" numbered 29021 published on this issue and the willingness of related institutions to be continued about this issue ${ }^{12}$. In this way, it may be possible to control monitoring of the financial consumer on the banks.

\section{References:}

1. Akcaer, G. (2000). 4839 Sayili Bankalar Kanunu’nda 4911 Sayili Yasa ile Yapilan Değişiklikler. Ankara Barosu Dergisi, (1), pp. 97128.

2. Battal, A. (2010). Bankalar Kanunu Şerhi Sorularla Banka Hukuku. 2. Baski, Gazi Kitapevi, Ankara.

3. BRSA. (2010). Stable Turkey Experience from Crisis. Working Paper, BRSA, Ankara.

4. Banking Law No.5411.

5. http://www.bddk.org.tr/WebSitesi/english/Legislation/14905banking _law_december_2013.pdf

6. Işiktac, M. C. (2010). Uygulamada Bankacilar icin Hukuk. Denizbank Yayinlari, Istanbul.

7. Kuntalp, E. (2004). Finansal Hizmetler Kanunu Tasarisi Taslaği'nin Bankalarin Denetim ve Gozetimine Ilişkin Hukumlerin Değerlendirilmesi. Istanbul Ticaret Universitesi Yayinlari TurkIsvicre Banka Hukuku Haftasi 16-17 Aralik, Istanbul, pp. 66-76.

8. Tanrioven, C., Kucukkaplan, I. ve Başci, E. S. (2006). Kurumsal Yonetim Acisindan Sahiplik ve Kontrol Yapisi ile Ust Duzey Yonetici Durumunun IMKB'de Faaliyet Gosteren Bankalarda Incelenmesi'. Iktisat, Işletme ve Finans, 21 (241), pp. 7-105.

9. TBB. (1998). Cumhuriyet Donemi Bankalar Kanunu ve Ilgili Duzenlemeler. TBB Yayin No: 208, Istanbul.

10. TBMM. (1994). Sanayi ve Teknoloji ve Ticaret Butce Komisyonu Kanun Hukmunde Kararname. Sayi: B.02.0.KKG/101-1-321/03857, 22 June 1994.

11. TBMM. (2005). Bankacilik Kanunu Tasarisi ve Avrupa Birliği Uyum ile Plan ve Butce Komisyonlari Raporlari. Sayi: B.02.0.KKG/1011028/1481, 30 March 2000.

\footnotetext{
${ }^{12}$ See. "Financial Access, Financial Education, Financial Consumer Protection Strategy and Action Plans", Official Gazette dated 5 June 2014.
} 
12. Tekinalp, U. (2009). Banka Hukukunun Esaslari. 2. Baski, Vedat Kitapcilik, Istanbul.

13. Yucel, F. Y. (2010). Hak ve Menfaatler Uzerine Bir Inceleme. Barolar Birliği Dergisi, (91), pp. 335-356. 